\title{
The Development and Significance of Standards for Smoking-Machine Methodology*
}

\author{
by
}

Richard R. Baker

British American Tobacco, Research \& Development Centre, Southampton, U.K.

\section{CONTENTS}

Summary

Introduction

1 Claims from BIALOUS and YACH's paper

2 Factors relevant to the development of smokingmachine methodology

3 Development of the standards

3.1 Development by the Federal Trade Commission in the USA

3.2 Development by national standards institutes, CORESTA and ISO

3.3 The Barclay conflict

3.4 Harmonisation of smoking-machine standards

4 The significance of smoke yields determined by standard smoking-machine methods

5 Inaccurate interpretations by BIALOUS and $\mathrm{YACH} 33$

6 Health claims about low "tar" cigarettes 34

6.1 Statements made by health scientists and authorities 34

6.2 Smoker compensation

6.3 Statements on the effect of smoking reduced "tar" cigarettes

6.4 Comments by tobacco industry scientists 36

7 Conclusions 37

Acknowledgements $\quad 37$

$\begin{array}{ll}\text { References } & 37\end{array}$

\section{SUMMARY}

BIALOUS and YACH have recently published an article in Tobacco Control in which they claim that all smokingmachine standards stem from a method developed unilaterally by the tobacco industry within the Cooperation Centre for Scientific Research Relative to Tobacco (CORESTA). Using a few highly selective quotations from internal tobacco company memos, they allege, inter alia, that the tobacco industry has changed the method to suit its own needs, that because humans do not smoke like machines the standards are of little value, and that the tobacco industry has unjustifiably made health claims about low "tar" cigarettes. The objectives of this paper are to review the development of smoking-machine methodology and standards, involvement of relative parties, outline the significance of the results and explore the validity of BIALOUS and YACH's claims. The large volume of published scientific information on the subject together with other information in the public domain has been consulted. When this information is taken into account it becomes obvious that the very narrow and restricted literature base of BIALOUS and YACH's analysis has resulted in them, perhaps inadvertedly, making factual errors, drawing wrong conclusions and writing inaccurate statements on many aspects of the subject.

The first smoking-machine standard was specified by the Federal Trade Commission (FTC), a federal government agency in the USA, in 1966. The CORESTA Recommended Method, similar in many aspects to that of the FTC, was developed in the late 1960s and published in 1969. Small differences in the butt lengths, smoke collection and analytical procedures in methods used in various countries including Germany, Canada and the UK, developed later, resulted in about a $10 \%$ difference in smoke "tar" yields. These differences in methodology were harmonised in a common International Organisation for Standardisation (ISO) Standard Method in 1991, after a considerable amount of interlaboratory comparisons of the developing methodology had been undertaken by CORESTA.

As acknowledged by BIALOUS and YACH, the purpose of the standards is to determine the "tar", nicotine and carbon monoxide content of cigarette smoke when the cigarette is smoked under precisely defined conditions, and hence to allow a comparison of the yields from different cigarettes when smoked under identical conditions. Such yields are not predictive of the yields humans obtain when smoking, nor were they ever expected to be so, since no two smokers smoke exactly the same nor does a smoker smoke a cigarette the same way on every occasion. This purpose has been stated consistently many times, originally by the FTC in 1967 and subsequently in the scientific literature, published by the tobacco industry and health/regulatory authorities, over the last 35 years. 
From the 1950s onwards numerous public health scientists have advocated that lower "tar" cigarettes should be developed on the grounds that they may reduce to some extent the risks of smoking, while at the same time advocating that the best way to avoid risks is not to smoke. Some health authorities have used the standard machine-smoking yields to set limits on "tar" as a way of reducing the health impact of cigarette use. The tobacco industry has co-operated with these health authorities by developing cigarettes with lower "tar" but has also followed public health advice by not advertising lower "tar" cigarettes as safe cigarettes.

The available evidence, taken as a whole, indicates that compensation by smokers who switch from a high to a low "tar" cigarette is partial in the short term, and that such smokers do obtain a reduction in smoke component uptake. [Beitr. Tabakforsch. Int. 20 (2002) 23-41]

\section{ZUSAMMENFASSUNG}

BIALOUS and YACH haben kürzlich einen Artikel in Tobacco Control publiziert, in welchem sie behaupten, dass alle Standards für Cigaretten-Abrauchmaschinen auf eine Methode zurückgehen, die einseitig von der Tabakindustrie im Rahmen des Cooperation Center for Scientific Research Relative to Tobacco (CORESTA) entwickelt wurde. Indem die Autoren einige höchst selektive Zitate aus internen Memos der Tabakindustrie verwenden, behaupten sie unter anderem, dass die Tabakindustrie die Methode verändert habe, um ihren eigenen Bedürfnissen zu entsprechen, und die Standards von geringem Wert seien, weil Raucher nicht wie Maschinen rauchen, und dass die Tabakindustrie ungerechtfertigterweise Gesundheitsaussagen über Cigaretten mit niedrigem Kondensatwert aufstellt.

Das Ziel dieser Arbeit ist es, eine Übersicht über die Entwicklung der Methoden und Standards von Rauchmaschinen $\mathrm{zu}$ geben, die Einflußnahme interessierter Parteien und die Bedeutung der Ergebnisse aufzuzeigen, sowie die Gültigkeit der Aussagen von BIALOUS und YACH zu untersuchen. Die Vielzahl publizierter wissenschaftlicher Arbeiten zu diesem Thema sowie andere veröffentlichte Informationen wurden zur Bewertung herangezogen. Unter Berücksichtigung all dieser Informationen wird deutlich, dass die sehr enge und begrenzte Literaturgrundlage der Analyse von BIALOUS and YACH dazu geführt hat, dass die Autoren, vielleicht unbeabsichtigt, tatsächlich Fehler begingen, indem sie die falschen Schlußfolgerungen zogen und fehlerhafte Behauptungen über viele Aspekte dieser Thematik aufstellten.

Der erste Standard für Rauchmaschinen wurde von der Federal Trade Commission (FTC), einer staatlichen Regierungsbehörde in den USA, 1966 spezifiziert. Die von der CORESTA empfohlene Methode, die in vielen Aspekten derjenigen der FTC entspricht, wurde Ende der 1960er Jahre entwickelt und im Jahr 1969 publiziert. Die geringfügigen Unterschiede in der Stummellänge, bei der Sammlung des Rauchs und den analytischen Verfahren der Methoden, die in vielen Ländern einschließlich Deutschland, Canada und Großbritannien angewendet und später weiterentwickelt wurden, führten bei der Ermittlung des Kondensatgehalts im
Rauch zu einem Unterschied von ungefähr 10\%. Diese Unterschiede in der Methodik wurden in einer International Organisation for Standardisation (ISO) Standard Methode im Jahre 1991 harmonisiert, nachdem umfangreiche Vergleiche zwischen den Labors bei der entwickelten Methodik im Rahmen der CORESTA durchgeführt worden waren. Wie von BIALOUS and YACH anerkannt wird, ist der Zweck von Standards, den Kondensat-, Nikotin- und Kohlenmonoxidgehalt im Cigarettenrauch zu bestimmen, wenn die Cigarette unter genau definierten Bedingungen geraucht wird, um somit einen Vergleich der ermittelten Konzentrationen zwischen verschiedenen Cigaretten, die unter den gleichen Bedingungen geraucht wurden, zu ermöglichen. Diese ermittelten Werte erlauben keine Vorhersagen über die Aufnahmemengen durch den Raucher, was auch zu keiner Zeit erwartet wurde, da keine zwei Raucher exakt identisch rauchen und auch ein Raucher eine Cigarette nicht immer in der gleichen Weise raucht. Dieser Zweck wurde konsequent viele Male angeführt, zunächst von der FTC im Jahre 1967 und nachfolgend während der letzten 35 Jahre in den wissenschaftlichen Publikationen der Tabakindustrie und der Gesundheits/Überwachungsbehörden.

Seit den 1950iger Jahren haben es viele Wissenschaftler des öffentlichen Gesundheitswesens befürwortet, dass Cigaretten mit einem niedrigeren Kondensatgehalt entwickelt werden sollten, um dadurch die Risiken des Rauchens in einem gewissen Umfang zu verringern, während sie gleichzeitig dafür eingetreten sind, dass der beste Weg Risiken zu vermeiden das Nichtrauchen sei. Einige Gesundheitsbehörden haben die durch Abrauch-Standards ermittelten Rauchausbeuten zur Festsetzung von Höchstwerten für Kondensat als ein Mittel genutzt, um die mit dem Rauchen verbundenen Risiken zu reduzieren. Die Tabakindustrie hat mit diesen Gesundheitsbehörden zusammengearbeitet, indem sie Cigaretten mit niedrigerem Kondensatgehalt entwickelt hat. Dabei ist sie jedoch auch dem Rat des öffentlichen Gesundheitswesens gefolgt und hat Cigaretten mit niedrigerem Kondensatgehalt in der Werbung nicht als ,sichere“ Cigaretten bezeichnet.

Die verfügbaren Hinweise zusammengenommen deuten darauf hin, dass die Kompensation bei Rauchern, die von einer Cigarette mit hohem Kondensatgehalt zu einer Cigarette mit niedrigem Kondensatgehalt wechseln, kurzfristig partiell erfolgt, und dass bei diesen Rauchern eine Reduzierung der aufgenommenen Rauchinhaltsstoffe erreicht wird. [Beitr. Tabakforsch. Int. 20 (2002) 23-41]

\section{RESUME}

BiALOUS and YACH ont récemment publié dans Tobacco Control, une étude dans laquelle ils prétendent que toutes les méthodes normalisées (standards) de fumage sur machine sont unilatéralement développées par l'industrie du tabac dans le cadre du Centre de Coopération pour les Recherches Scientifiques Relatives au Tabac (CORESTA). En utilisant quelques citations particulièrement sélectives de mémos internes de l'industrie du tabac, ils affirment, entre autres, que l'industrie du tabac a modifié la méthode pour satisfaire à ses besoins, parce que les hommes ne fument pas comme des machines les méthodes normalisées 
ont une faible valeur, et que l'industrie du tabac a, d'une façon injustifiable, fait des affirmations sur les effets sanitaires des cigarettes à faible taux de goudrons.

Cette communication a pour objectif de passer en revue le développement de la méthodologie et les standards des machines à fumer, l'implication des différents partis , de démontrer l'importance des résultats et examiner la validité des affirmations faites par BIALOUS and YACH. La vaste gamme de publications scientifiques sur ce sujet ainsi que d'autres informations disponibles au public ont été consultées. En tenant compte de toutes ces informations, il devient évident que la littérature limitée et restreinte qui a servi de base pour l'analyse de BIALOUS and YACH a amené les auteurs à commettre des fautes factuelles, à tirer de fausses conclusions et à écrire des commentaires erronées sur de nombreux aspects du sujet.

La première méthode normalisée de fumage sur machine a été spécifiée en 1966 par la Federal Trade Commission (FTC), une agence fédérale du gouvernement des USA. La Méthode Recommandée CORESTA, similaire en beaucoup d'aspects à celle de la FTC, a été développée à la fin des années 1960 et publiée en 1969. Les petites différences dans la longueur des mégots, le piégeage de la fumée et les procédures analytiques entre les méthodes appliquées dans de nombreux pays, y compris l'Allemagne, le Canada et le Royaume Uni (UK), et qui ont été développées plus tard, ont engendré une différence pouvant atteindre jusqu'à $10 \%$ dans le rendement en goudron de la fumée. Ces différences entre les méthodes ont été harmonisées par l'élaboration d'une Méthode Standard ISO (International Organization for Standardization) en 1991, après les comparaisons considérables des méthodes développées entre les laboratoires ont été effectuées dans le cadre de la CORESTA.

Comme indiqué par BIALOUS and YACH, l'objet des méthodes normalisées est de déterminer le rendement en goudron, nicotine et monoxyde de carbone dans la fumée de cigarette quand les cigarettes sont fumées en conditions normalisées, et ainsi de pouvoir comparer les rendements des différentes cigarettes fumées en conditions identiques. Ces rendements ne permettent pas de faire de prédictions sur l'absorption des substances par le fumeur, ce qui n'a jamais été supposé, car deux fumeurs ne fument jamais exactement de la même façon, et un fumeur ne fume pas toujours la cigarette de la même façon. Cet objet des méthodes recommandées a été affirmé dès l'origine en 1967 par la FTC et par la suite dans la littérature scientifique publiée par l'industrie du tabac et les autorités de santé/de surveillance au cours des 35 dernières années.

A partir de 1950, de nombreux chercheurs de la santé publique ont plaidé pour le développement de cigarettes à faible rendement en goudron, pour permettre de réduire, dans une certaine mesure, les risques pour le fumeur, tout en recommandant en même temps que la meilleure façon d'éviter des risques est de ne pas fumer. Certaines autorités de santé ont utilisé les rendements normalisés obtenus par fumage sur machine pour plafonner les taux de goudron, pour réduire les risques engendrés par le fumage des cigarettes. L'industrie du tabac a coopéré avec ces autorités de santé et a développé des cigarettes à rendement plus faible en goudron tout en respectant également le conseil de la santé publique de ne pas indiquer dans la publicité que les cigarettes à faible rendement en goudron étaient des cigarettes «sûres».

L'ensemble des résultats des études disponibles indiquent que la compensation par les fumeurs qui changent d'une cigarette à rendement élevé en goudron à une cigarette à rendement faible est partielle à court terme, et que de tels fumeurs obtiennent une réduction de l' absorption des composants de la fumée. [Beitr. Tabakforsch. Int. 20 (2002) 23-41]

\section{INTRODUCTION}

In a recent article published in Tobacco Control, BIALOUS and YACH (1) create the impression that international standards for the machine smoking of cigarettes were more or less foisted on the smoking public unilaterally by the tobacco industry by its influence on the International Organisation for Standardisation (ISO) through control of the Cooperation Centre for Scientific Research Relative to Tobacco (CORESTA). They imply that the tobacco industry has sought to present their products in the most favourable light with these standard methods and has attempted to mislead the public, because smoke yields obtained using these standards are not the same as those obtained by real smokers. Various quotes from internal tobacco company documents retrieved from the Internet were used to support these hypotheses.

I am sure that BIALOUS and YACH wrote the paper with the objective of presenting an unbiased view of the development of the subject. However, by concentrating on selected quotes from internal company documents, taken out of context, and at the same time omitting much information that is available in the scientific literature or on public records, the authors have inadvertently created an incorrect impression.

Some inaccuracies in BIALOUS and YACH's paper have been pointed out in two Letters to the Editor of Tobacco Control (1a,1b). However, they dismiss the criticisms and claim they indicate an "incomplete reading" of their paper (1c).

The purposes of this paper are to:

a) Review the development of smoking-machine methodology and standards.

b) Describe the involvement of relevant parties.

c) Outline the significance of results obtained using the standards.

d) Explore the validity of some of BIALOUS and YACH's allegations.

It is hoped that these topics will be put into a more valid historical perspective.

\section{CLAIMS FROM BIALOUS AND YACH'S PAPER}

Although many points and implications are made by BIALOUS and YACH, the main, broad assertions from their analysis are as follows:

a) All cigarette smoking-machine standards (FTC, ISO, German DIN, etc.) are based on the CORESTA method, developed by tobacco industry scientists only. 
b) The tobacco industry, through CORESTA, has changed the standard methodology in order to lower smoke yields and get around government regulations, specifically the European "tar" ceiling directives.

c) Since humans do not smoke like machines, "tar" and nicotine yields obtained from a smoking machine are of no value and low "tar" cigarette designs are developed to cheat the smoking machine.

d) The tobacco industry uses labels such as "low tar" and "light" to imply unjustifiably that such cigarettes are less hazardous than higher "tar" cigarettes.

\section{FACTORS RELEVANT TO THE DEVELOPMENT OF SMOKING-MACHINE METHODOLOGY}

The purpose of this section is not to exhaustively review all the factors involved in the development of standards for smoking-machine methodology. Rather, it is to indicate topics which need to be considered, and some of the technical issues which arose during the time that the methods were under development.

Smoking machines of one sort or another have been used for almost 100 years to collect smoke for subsequent analysis. There are three essential elements and requirements for a smoking-machine method for such work:

a) It should enable the cigarette to be smoked mechanically under specified conditions in a reproducible and controlled manner.

b) The smoke should be collected quantitatively and consistently.

c) The smoke should be analysed in a reproducible manner.

WYNDER and HOFFMANN (2) and DEBARDELEBEN et al. (3) have described the early development of smoking machines. The first reported devices in Germany and by the US Department of Agriculture in the early 1900s used continuous suction to mechanically smoke the cigarette. This was followed by the use of interrupted suction to simulate the puff/smoulder regime of human smoking. In the early machines the suction was interrupted manually, but by the 1920s and early 1930s automatic timing devices were developed. The smoking machine took puffs at either constant volume or constant duration at set intervals.

In 1933 PFYL (4) recognised the need to standardise "the artificial smoking of tobacco products" and developed a machine following observations with seven human smokers who took puff volumes varying between 27 and $61 \mathrm{~mL}$. However, the first widely-used smoking machine was described by BRADFORD et al. in 1936 (5). This machine was first used to enable cigarette manufacturers to evaluate the mainstream smoke yields of their products for quality assurance purposes, i.e. to ensure product consistency. The machine developed by BRADFORD et al. was a constant volume machine that used a water column to regulate the puff volume. Versions of this machine were used for the next 25 years, most often as a four cigarette-port model. The machine took one puff per cigarette every $58 \mathrm{sec}$, with the volume pre-set by the operator. In their original paper,
BRADFORD et al. (5) used a puff volume of $35 \mathrm{~mL}$, selected arbitrarily. However, a disadvantage with this smoking machine, as with all constant volume machines, was that the puff duration was dependent on the pressure drop of the cigarette being smoked, with low pressure drop cigarettes giving short durations. Thus the puff duration could vary from cigarette to cigarette and also with the same cigarette as it was smoked and its pressure drop consequently varied. Other industrial laboratories up to the 1950 s were using constant puff duration (flow rate) smoking machines. However, these had the equivalent disadvantage to BRADFORD et al.'s machine: the puff volume was dependent on the pressure drop of the cigarettes being smoked. These difficulties with pressure drop gave relatively poor reproducibility with the machines. Modifications were made to BRADFORD et al.'s machine, some twenty years after its first use, by replacing the water column with a large vacuum reservoir and installing a pressure-drop regulator $(6,7)$, giving greater reproducibility.

BRADFORD et al. (5) also recognised that the two principles employed in producing the puff would give rise to two different puff profiles (plot of flow rate against time). The constant volume machine produced a "bell-shaped" profile whereas the constant flow machines produced essentially a "square-wave" profile.

The development of smoking machines accelerated from the late 1950s onwards. Development and manufacture of the machines moved from tobacco manufacturers to specialist companies, principally Phipps and Bird Inc. (USA), Cigarette Components Ltd. (UK) and Borgwaldt GmbH (Germany). The variability problems with the early machines were eliminated. Constant flow machines are now rarely used. The general operational principle of all modern smoking machines is the production of a "bell-shaped" puff of fixed volume using a tightly sealed motor-driven piston or syringe. These overcame the variability problems with cigarettes of different pressure drops. Various machines are now readily available from manufacturers in the UK and Germany, incorporating various levels of automation and computer control. Smoking machines with up to 100 cigarette ports are available. Two types of constant volume machines have dominated smoking methodology for many years: linear smoking machines and rotary smoking machines. Linear simultaneous smoking machines are produced by Filtrona Instruments and Automation Ltd. (now called Cerulean Ltd.) in the UK. Rotary smoking machines are manufactured by Borgwaldt Technik in Germany.

In parallel with development of the smoking machine itself, large amounts of work have been done on means of collecting both the particulate and vapour phases of the smoke. Because of the complex nature of tobacco smoke, the design of a perfect collection system is challenging. DUBE and GREEN (8) have reviewed the methods of collecting cigarette smoke and list the criteria of an ideal smoke collection system as: efficient, simple construction, easily cleaned, reproducible, reliable, low pressure drop, minimum volume, eliminates possibilities of artefact formation, and quantitative. No one smoke trap fulfils all these requirements for total smoke collection.

In the original paper by BRADFORD et al. (5), the particulate phase of smoke was collected by using gravity and 
bubbling the smoke through flasks containing alcohol and water. Since then a variety of smoke collection methods has been used (8): electrostatic precipitation; adsorbents such as activated charcoal, silica gel, molecular sieves and Tenax ${ }^{\circledR}$; solvent traps and trapping on glass fibre (Cambridge) filters. Each of these methods gives slightly different values for the components in the particulate and vapour phases of the collected smoke.

The use of the Cambridge filter pad for collecting the particulate phase of smoke was described in 1959 by WARTMAN et al. (9). In this method the mainstream smoke exiting from the mouthend of the cigarette is immediately drawn through a Cambridge filter pad, number CM-113 (a glass fibre filter stabilised by an organic binder, originally manufactured by the Cambridge Filter Corporation, Syracuse, New York). This filter traps the particles present in the cigarette smoke aerosol and is $99.9 \%$ efficient for particles larger than $0.1 \mu \mathrm{m}$ in diameter. The Cambridge filter pad has gained widespread use for trapping the particulate phase of smoke and separating it from the vapour phase. However, the trapping efficiency of a Cambridge filter is a function of a number of factors, including the nature and amount of material being collected, the flow through the filter, the temperature and moisture level of the filter (10), as well as the condition of the cigarette at the time of smoking (moisture content, etc.). However, these factors have been controlled by careful selection of the Cambridge filter parameters.

The final consideration in the development of smokingmachine methodology is the analysis of the smoke collected. To date, standards have been developed for the analysis of the "tar", nicotine and carbon monoxide content of the smoke. "Tar" is defined as the weight of total particulate matter (TPM) collected in the smoke less the weight of nicotine and water. In principle TPM is a simple measurement which can be quantified by the weight of particulate matter collected on the smoke trapping device. The determination of water and nicotine in the particulate matter is more complex since there are several methods for each substance and each may give slightly different answers. The following methods have been proposed for the determination of the water content of TPM, with the date of the first report in the scientific literature given:

- Karl Fischer titration, 1960 (11)

- Near infrared spectrophotometry, 1961 (12)

- Gas chromatography, 1962 (13).

Many studies are reported in the smoke chemistry literature which compare values obtained by determinations with the above methods, and which also report modifications to these methods.

The following methods have been proposed for the determination of nicotine, with the date of the first report in the scientific literature given:

- Steam distillation followed by treatment with silicotungstic acid, 1939 (14)

- Ultraviolet spectrophotometry, 1950 (15)

- "Griffith still" - improved distillation method adopted by many analytical laboratories, 1948 (16)
- Titration with perchloric acid in acetic acid, 1955 (17)

- Rapid steam distillation method, $1957(6,18)$

- Gas chromatography, 1959 (19)

- Extraction with methanol-hydrochloric acid and activated carbon treatment, 1967 (20)

- Automatic method following extraction with 2-propanol, 1969 (21).

There is also a large volume of published papers on modifications to the above methods and comparisons of values obtained using them.

In the development of any standardised method, all of the many methods available have to be carefully compared and the most suitable selected.

\section{DEVELOPMENT OF THE STANDARDS}

'Standards' are documented agreements containing technical specifications or concise criteria to be used consistently as rules guidelines. By the 1960s there was a variety of smoking-machine devices, smoke collection systems and smoke analytical methods available, each giving slightly different results. A large number of combinations of these three elements was possible so that almost every smoke laboratory world-wide had its own unique methodology, all producing smoke analytical data that were not properly comparable. The need for standardised smoking-machine methodology was urgently needed, as pointed out by WYNDER and HOFFMANN in 1967 (2).

\subsection{Development by the Federal Trade Commission in the USA}

The Federal Trade Commission (FTC) in the USA is a federal government agency that enforces a variety of federal antitrust and consumer protection laws. The Federal Cigarette Labelling and Advertising Act of 1966 requires the FTC to submit annual reports to Congress on cigarette labelling, advertising practices and recommendations for legislation. The events leading to the development of the FTC smoking method in the USA have been described in detail in separate reviews by PEELER (22) of the FTC, RODGMAN (23) and BORGERDING (24).

Several dose-response studies and statements from government and health scientists in the 1950s and 1960s indicated that smoking lower "tar" cigarettes might be a less hazardous form of smoking (see Section 6 below). The FTC proposed that the consumer should be aware of the "tar" yields of marketed cigarettes in order to make an informed choice. Consequently, US cigarette manufacturers designed and manufactured cigarettes over a range of "tar" values, and advertised the "tar" values, each company using its own unique combination of smoking-machine methodology to measure the "tar". However, according to PEELER (22), this produced "a multitude of inconsistent non-comparable claims that did not give the consumer a meaningful opportunity to assess the relative tar delivery of competing brands." In the absence of a standardised method the US cigarette manufacturers agreed with the FTC to eliminate "tar" and nicotine values from advertising in 1960. 
The publication of the report of the US Surgeon General's committee that considered smoking and health in 1964 (25) gave the FTC impetus to develop standardised smokingmachine methodology to implement a labelling system for the "tar" and nicotine yields of US cigarette brands. On 25 March 1966 the FTC sent identical letters to each of the US cigarette manufacturers indicating that it intended to set up a standardised smoking-machine method (26). It also set up its own FTC Tobacco Research Laboratory in that year. The FTC then vigorously pursued its own implementation of methodology which it considered appropriate, guided of course by work that had already been undertaken in the tobacco industry laboratories and by the work of others. The resultant FTC procedure generally incorporated the best aspects of the various methodologies developed during the previous 30 years. These included the smoking parameters proposed by BRADFORD et al. in 1936 (5) of one puff of 35 $\mathrm{mL}$ volume and $2.0 \mathrm{~s}$ duration every minute; the Wartman et al. 1959 method (9) for the collection of TPM on a Cambridge filter, rigorously evaluated in an inter-laboratory collaborative study published by OGG in 1964 (27); and relevant aspects of procedures in the scientific literature for the analysis of water and nicotine in TPM. The standardised smoking-machine methodology selected by the FTC was, in fact, based primarily on that used in OGG's 1964 study (27), OGG being a scientist with the US Department of Agriculture.

The FTC adopted its method in 1966 with some minor refinements in $1967(28,29)$. The method was published in the scientific literature in 1969 (30). Its key parameters are summarised in Table 1. The FTC published its first list of mainstream "tar" and nicotine yields from 59 US cigarette brands with the method in 1967 (31), extending it to 122 brands in the following year. A subsequent collaborative study performed by ten laboratories showed good agreement for cigarettes that yielded less than $20 \mathrm{mg}$ "tar" and $1 \mathrm{mg}$ nicotine (32). In 1970 the US tobacco industry agreed with the FTC to include the FTC "tar" and nicotine yields of its brands in all advertising. The FTC added the determination of carbon monoxide in cigarette smoke to its methodology in 1981 (33).

The FTC stated very clearly the purpose of their standard smoking methodology: to rank cigarette brands by mainstream yields of "tar", nicotine and subsequently carbon monoxide, generated under standard and reproducible conditions $(31,33)$.

During the period in the mid 1960s when the FTC was deliberating and setting up its method, the US tobacco industry provided the FTC with various comments and criticisms of the method, in some instances accompanied by laboratory data to support the validity of the comments (23). These comments included the following:

- "Tar" and nicotine yields obtained under standard machine smoking would not inform the smoker of the precise amounts of "tar" or nicotine that they would receive during their smoking of the cigarette.

- Individual smokers do not smoke with the same parameters as the standard method and the number of puffs taken varies from smoker to smoker. Indeed, ADAMS (34), at that time a scientist with Imperial
Tobacco in the UK, presented extensive data on this subject at the 1966 Tobacco Chemists' Research Conference in Winston-Salem, North Carolina. Delegates from the FTC were present at this conference. PFYL had made the same point in a paper published in 1933 (4). Furthermore, RodGMAN (23) cites seven other studies on this subject published between 1937 and 1961.

- The "tar" content of smoke is a very simplistic measure since the composition of "tar" from different cigarettes can differ.

- The standard methodology does not take into account variations in ambient temperature, humidity and pressure which smokers in different parts of the world experience.

The FTC acknowledged these comments (29) but was not able to take all of them into account during its method development.

The US tobacco companies subsequently performed a detailed collaborative study on the FTC procedure (35). Several small procedural changes were recommended and in the publication it was reiterated that "Cigarette smokers vary greatly in their manner of smoking ..."

\subsection{Developments by national standards institutes, CORESTA and ISO}

In parallel to activities in the USA, national standards institutes in various countries also developed their own standard smoking methods. In the UK the smoking-machine parameters used originally in 1958 were a $25 \mathrm{~mL}$ puff of $2 \mathrm{~s}$ duration taken once per minute to a butt length of $18 \mathrm{~mm}$ (36). These machine parameters gave the same puff number and butt length as the average acquired from a survey of 312 UK smokers. In 1970 the standard puff volume used in the UK was changed to $35 \mathrm{~mL}$, and the butt length was changed to $20 \mathrm{~mm}$, based on market research (37). These changes in the smoking machine parameters produced no change in the ranking of "tar" and nicotine yields of British cigarettes.

The resultant standard method used in the UK was published by the UK Tobacco Research Council in 1972 (38) and is summarised in Table 1 . The scientific validity of the smoking and analytical procedures was established after exhaustive collaborative testing. Although a British Standards Institute (BSI) method was published in 1987 (39), identical to the ISO method (Table 1), the Tobacco Research Council method continued to be used by the Laboratory of the Government Chemist in Britain until 1992.

The smoking parameters specified in the UK Tobacco Research Council method (38) and the German Standards Institute, DIN (Deutsches Institut für Normung) method (40) are summarised in Table 1, although they were both superseded by the ISO methods (41) after 1991. The British and German methods originally differed in the make of smoking machine used (Filtrona linear machines in the UK and Borgwaldt rotary machines in Germany), the method of smoke collection (Cambridge filter pad in the UK and electrostatic precipitation in Germany) and the butt length at which the machine smoking was stopped. 


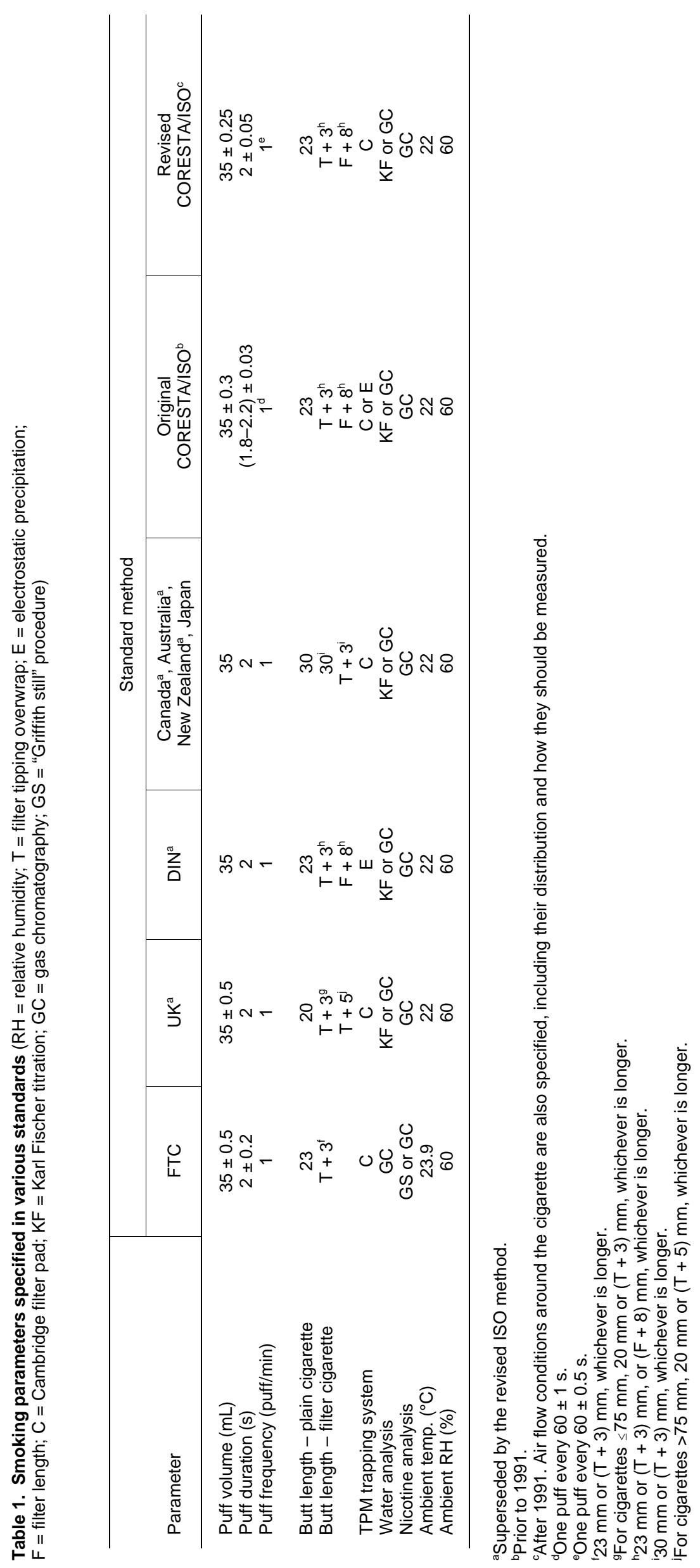


The original smoking parameters specified in Canada, Australia, New Zealand and Japan are summarised in Table 1 although, with the exception of Japan, they were superseded by the revised ISO methods. The original specifications included longer butt lengths than in other standards. The composition of the national standards institute committees which developed and adopted the methods depended on the particular country. In the UK, for example, the BSI consists of representatives from the UK cigarette manufacturers in equal partnership with representatives of the Laboratory of the Government Chemist (LGC). The "tar" and nicotine yields of British cigarettes were determined by the LGC from 1972 to 1992 using the UK (Tobacco Research Council) method (38), and from 1992 onwards using the revised ISO methods.

CORESTA (Centre de COopération pour les REcherches Scientifiques Relatives au TAbac) is an international organisation of tobacco researchers with its headquarters in Paris. It was formed in 1956 and now consists of 188 member organisations from 51 countries, all of whom have an involvement in tobacco science. The membership comprises tobacco companies ( $44 \%$ of members), government tobacco monopolies (6\% of members), supplier companies (paper, filter materials, flavours, etc., $22 \%$ of members), tobacco growers (12\%), research institutes $(12 \%)$, instrument/machine manufacturers $(3 \%)$ and universities (1\%). Scientific activities within CORESTA are conducted through Task Forces and Sub Groups, each devoted to a single specialist topic. The activities of the Task Forces and Sub Groups are directed by the Scientific Commission, an elected body that comprises twenty technical experts in a broad variety of scientific disciplines. In the late 1960s CORESTA formed a Task Force to develop a recommended international method for machinesmoking cigarettes and its method was published in 1969 (42) and is summarised in Table 1.

The International Organisation for Standardisation (ISO) is a network of national standards institutes from 140 countries working towards creating technical standards in a variety of technological subjects. There are 187 Technical Committees within ISO, each devoted to work within a particular commodity or technical subject. In 1968, on the initiative of the German Standards Institute (DIN), a Technical Committee was formed within ISO (ISO Technical Committee 126), to work on producing standards for tobacco products. There are 33 national bodies, 23 observer national bodies, and 3 liaison members within Technical Committee 126. (Liaison members are relevant technical organisations which have no voting rights.) CORESTA is a liaison member. In 1970 this Technical Committee set up a Working Group of experts to consider an ISO standard for machine-smoking cigarettes. This group originally used the UK method (38) as the basis for its development, changing the butt lengths to those used in the CORESTA method. The first edition of the resultant ISO Standard was published in 1977 (43). The ISO Standards, accepted world-wide, were essentially identical to the CORESTA Recommended Methods. They originally included both Cambridge filter (44) and electrostatic trap (45) methodology for the collection of the particulate phase of smoke, thus covering both methods in use in the UK and Germany at the time.
All of the standard methods summarised in Table 1 use the same puffing parameters: a $35 \mathrm{~mL}$ puff of $2.0 \mathrm{~s}$ duration taken once per minute. These are the parameters arbitrarily used in the original publication of BRADFORD et al. in 1936 (5), used in the 1964 collaborative study published by OGG of the US Department of Agriculture (27), and subsequently adopted by the FTC in 1966 (28). In no way did the tobacco industry have any control of the FTC's adoption of these parameters. These puffing parameters were subsequently adopted by national standards bodies, CORESTA and ISO, presumably to retain consistency with the USA.

Two issues occurred in the 1980s which necessitated further developments of the standard methods. One was the so-called "Barclay conflict" and the other was the requirement to harmonise the small differences in the standard methodology. These will be dealt with respectively in the next two sections.

\subsection{The Barclay conflict}

In 1980 the Brown and Williamson Tobacco Corporation, the American company in the British American Tobacco Group, launched a new cigarette brand in the USA, Barclay. This cigarette had a novel filter which incorporated four axial channels along its periphery and opening at the mouth end of the cigarette. In combination with a ventilation zone, this filter allowed an influx of a large amount of air during smoking. Under the FTC machine-smoking conditions this cigarette generated a very low "tar" yield of $1 \mathrm{mg}$. However, scientists in other tobacco companies believed that this yield gave an unfair comparison to the yield obtained from all other cigarettes when smoked under the FTC smoking conditions. They argued that the lips of a real smoker of Barclay would crush the channels or block the mouth end of the channels, thereby destroying the ventilation system and obtaining a higher "tar" yield than under the machine-smoking conditions. This resulted in protracted arguments between tobacco companies, as well as court action, on how to compare fairly the yield of "tar" and nicotine from Barclay under standard machine-smoking conditions with that from other cigarettes. In 1983 the FTC declared that the testing of channel-ventilated filter cigarettes was outside the scope of its method (22).

The situation was eventually resolved within CORESTA, where a Task Force was set up in 1986 to determine how the smoke yields from cigarettes with channel-ventilated filters could be compared fairly to other cigarettes in the standard smoking methodology (in the CORESTA forum this was the CORESTA method (42), which was very similar to the FTC method - see Table 1). As a result of this work, the CORESTA smoking method was subsequently modified in 1989 (46) by incorporating a special cigarette holder which sealed the channel openings at the mouth end of the filter. This modification to the methodology increased the standard machine "tar" yield of Barclay from 1 to $5 \mathrm{mg}$. This was considered to be a more realistic comparison to the standard machine yields from other cigarettes.

It should be noted that the above arguments apply to channel-ventilated filter cigarettes only. The extent to 
which real smokers may inadvertently block the ventilation zone of a conventionally-ventilated cigarette with their lips or fingers, and the consequences on smoke yields, have been discussed in the scientific literature for twenty years. A recent review of the subject, by BAKER and LEWIS (47), has concluded that the relatively small incidence of ventilation zone blocking, as it occurs in practice amongst smokers, has only a relatively minor effect on human smoke yields compared to other smoker behaviour factors.

\subsection{Harmonisation of smoking-machine standards}

By the late 1980s various standard methods were in use around the world for determining the levels of "tar", nicotine and carbon monoxide in cigarette smoke, including the FTC, ISO and CORESTA methods and those used by authorities in the UK, Germany, Canada, Australia, New Zealand and Japan (Table 1). These methods were effectively identical in the puffing parameters used but differed in the type of smoking machine used, the butt length specified, the method of collection of the smoke particulate phase and in some aspects of the analytical methodology. In addition, it was realised that the air flow conditions around the cigarettes on rotary and linear smoking machines differed. Such differences affect the burning rate of the cigarette and hence the smoke yields. When the smoke yields of identical cigarettes were determined with these various methods, small differences were observed (48):

$$
\begin{aligned}
\mathrm{ISO} & =\mathrm{CORESTA}>\mathrm{UK}>\mathrm{FTC}>\mathrm{DIN}>\text { Canada } \\
& =\text { Australia }=\text { New Zealand }=\text { Japan }
\end{aligned}
$$

The differences from the highest to lowest values were of the order of $10 \%$ and this is equivalent to a $1.5 \mathrm{mg}$ difference for a cigarette yielding $15 \mathrm{mg}$ "tar".

In 1988 the European Economic Community indicated that it would set a $15 \mathrm{mg}$ "tar" ceiling on all cigarettes sold in Europe from 1993, as a first step in reducing it to $12 \mathrm{mg}$ in 1997. This was issued as an official directive to all Member States in 1990 (49). One consequence of this could be, for example, that the "tar" yield of a cigarette measured in Britain using the UK method could be above $15 \mathrm{mg}$ while that of the same cigarette measured in Germany using the DIN method could be below $15 \mathrm{mg}$. This was clearly illogical and a standard, common method was needed across Europe. In addition, there is a requirement in ISO that its standard methods should be reviewed every five years and revised if necessary. Based on the type of differences outlined above, in 1988 ISO decided that there was a need to revise the standard smoking methods used world-wide and produce a single standard method. ISO asked CORESTA to undertake the necessary experimental work to produce a revised standard.

THOMSEN (48) has described the subsequent very large amount of experimental work and collaborative experiments undertaken by CORESTA between 1989 and 1992. The standard method developed is a very comprehensive set of procedures which describe exactly how the cigarettes should be sampled from the market place, environmentally conditioned prior to machine smoking, the environmental con- ditions (temperature, relative humidity and air flow) during the smoking, exact setting up and operation procedure for the smoking machines as well as details of the collection and chemical analysis of the smoke (summarised in Table 1). The key changes to the revised ISO methodology were that: (i) the smoke particulate matter collection was done by the Cambridge filter pad method only (rather than by either the Cambridge pad [44] or electrostatic precipitation [45]), and (ii) the air flow conditions around the cigarettes during smoking were precisely stipulated. The procedures were accepted by ISO in 1991 as the standard method. The German DIN and British BSI methods then became verbatim equivalent to the ISO Standards. The standards used in Canada, Australia and New Zealand were also superseded by the revised ISO method. In response to the revised ISO Standard, the two manufacturers of smoking machines, Filtona in the UK and Borgwaldt in Germany, made changes to the cabinets surrounding the smoking machines to better regulate the air flow conditions around the cigarettes. As a result of various national bodies changing from their own standard to the revised ISO Standard in the early 1990s, machine smoke yields of some brands determined in the UK decreased by up to $0.5 \mathrm{mg}$ "tar", while smoke yields determined in Canada, Australia and New Zealand increased by up to $3 \mathrm{mg}$ "tar" for some brands.

It is a requirement of ISO that its standards should be tested in a collaborative study in which the repeatability $(r$, within-laboratory precision) and reproducibility ( $R$, amonglaboratories precision) are measured to a prescribed statistical procedure (50). The CORESTA Task Force undertaking this work conducted its collaborative study of the method with six types of cigarette with "tar" yields varying from 1 to $17 \mathrm{mg}$, and amongst 29 laboratories from 15 countries. This was the largest and most comprehensive collaborative study ever undertaken in CORESTA and its detailed results were published in 1991 (51).

Following the ISO requirement that its standards are revised, if necessary, every five years, some minor changes were also made to the written methods in 1996 and published in 1999 and 2000 (see reference 41). These were clarifications to the written text and did not affect the actual methodology.

It should be noted that the ISO Standards are now used world-wide with the exception of the USA and Japan where the slightly different FTC and Japanese methods, respectively, continue to be used (Table 1). Japan is likely to change to the ISO Standard in 2002. It should also be noted that the FTC has now suspended support for its method, has not completed an inquiry into whether there might be a better method, and has recommended that Congress consider giving authority over cigarette testing to a public health federal government agency (52b).

\section{THE SIGNIFICANCE OF SMOKE YIELDS DETERMINED BY STANDARD SMOKING- MACHINE METHODS}

Cigarettes are, of course, smoked by humans and humans smoke cigarettes in a variety of ways. It is well known that no two smokers smoke in identical ways; no single smoker 
smokes in the same way on all occasions. This was recognised by the FTC in $1967(22,29)$ and it is currently stated by the FTC (52). The yield of components in cigarette mainstream smoke depends upon the volume of puffs taken, the shape of the puff profile (the flow/time relationship), the number and frequency of puffs and the butt length left at the end of smoking (e.g. 53,54). The variations of smoking parameters observed with individual smokers are in the ranges of 20 to $80 \mathrm{~mL}$ for puff volume, 0.8 to $3.0 \mathrm{~s}$ for puff duration, 20 to $100 \mathrm{~s}$ for puff interval and 19 to $40 \mathrm{~mm}$ for butt length (e.g. 4,34,53-56).

As acknowledged by BIALOUS and YACH (1), the smokingmachine standards were developed specifically to determine smoke yields from cigarettes when the cigarette is smoked under a set of standard conditions. The standard smoking methods are reliable, validated analytical procedures for accurately determining mainstream yields of "tar", nicotine and carbon monoxide. Mainstream smoke yields determined by the standard smoking methods are appropriate for the ranking of cigarettes with respect to their yield. The specified smoking parameters, i.e. puff volume, duration, interval, etc., are well within established ranges of human smoking as indicated above. However, the smoke yields determined by the standard smoking methods do not necessarily correspond to the yields created by individual smokers. Smokers not only smoke different brands differently but they also smoke the same brand differently depending on a host social and environmental variables. As indicated in Section 3.1 above, these factors were transmitted to the FTC by the US tobacco industry in the mid 1960s and were well recognised by the FTC. The FTC stated clearly in $1967(22,29)$ that the purpose of measuring smoke yields by the standard method was "not to determine the amount of 'tar' and nicotine inhaled by any human smoker, but rather to determine the amount of 'tar' and nicotine generated when a cigarette is smoked by machine in accordance with the prescribed method." Other government committees have also recognised this purpose. For example the UK Independent Scientific Committee on Smoking and Health, which advised the UK government, made the following statement on machine-derived smoke yields in 1988 (57):

Critics of the machine smoking procedure have frequently failed to understand that values present in tables produced by the DHSS [Department of Health and Society Security] have never been intended to be actual yields obtained by any one smoker. Rather, they enable brands to be ranked. This allows inter-brand comparison under a standard test procedure, presenting the smoker with information to enable him to choose, if he so wishes, a lower yielding brand.

The main points were reiterated in a short position paper published by CORESTA in 1994 (58) which stated:

Mainstream yields determined by the standard smoking methods are appropriate for the ranking of cigarettes with respect to their yield. The machine results are not necessarily predictive of yields created by individual consumers.

The situation is analogous to the methodology used to measure fuel consumption in cars in several countries.
These fuel consumption data are determined under standard conditions of car velocity. No driver expects to match these on every occasion when a particular car model is driven; nor would two drivers expect to obtain identical figures when driving the same car. What is achieved by fuel consumption figures is a meaningful comparison of different models of car under standard conditions.

In practice, with cigarette smoking some smokers achieve "tar" and nicotine yields greater than those from the standard smoking method, while others achieve lower ones (e.g. 59). Rankings based upon standard methods give the consumer good qualitative guidance on relative cigarette mainstream smoke yields, but they are not necessarily predictive of absolute yields for each individual smoker. In 1994 H.A. Waxman, chairman of the US House of Representatives Sub-committee on Health and the Environment, requested the US National Cancer Institute to convene a panel of experts to ". . . review and make recommendations of the accuracy and appropriateness of the Federal Trade Commission's method for determining the relative 'tar' and nicotine content of cigarettes" (60). J. Steiger, chairman of the FTC, endorsed this request and a two-day meeting was subsequently held in December 1994. The panel consisted of ten scientists from diverse, non tobacco-industry backgrounds, and scientific presentations were made by fourteen experts in aspects of health, cigarette use and tobacco science. The panel recommended, inter alia, that the FTC method ". . . should also measure and publish information on the range of tar, nicotine and carbon monoxide yields that most smokers should expect from each cigarette sold in the United States" (60). A possible alternative FTC smoking regime is summarised in Table 2. However, the suggestion has not been developed further and a final decision from the FTC is still awaited. In the meantime, however, some regulatory authorities have introduced "intense" smoking regimes that incorporate extremes of puff volume, duration and frequency observed in human smoking, summarised in Table 2. These regulators include the federal government of Canada, the provincial government of British Columbia, and the health authorities of the Commonwealth of Massachusetts. These intense smoking regimes give, in absolute terms, larger mainstream smoke yields than the current ISO standard method. However, extensive smoke data obtained under different smoking machine regimes in studies conducted in the USA, UK and Canada indicate that product ranking obtained under different regimes are broadly similar $(24,54,61-66)$. This is not the case when $100 \%$ of the filter ventilation zone is blocked (64-66), but such a condition is rarely obtained with human smokers (47).

Some of the intense smoking regimes summarised in Table 2 include the blocking of the cigarette filter ventilation zone. KOZLOWSKI and O'CONNOR (67) have also suggested a "two stage" machine-smoking method that would progressively increase the intensity of the smoking regime as the standard smoke yields decreased, and could include blocking $50 \%$ of the filter vents. However, care should be taken in combining unrealistic vent blocking conditions with intense puffing regimes because these will lead to disproportionately high and misleading effects on yields compared to the human smoking situation (47). 
Table 2. Smoking machine parameters used or proposed by some regulatory authorities

\begin{tabular}{l|c|c|c|c}
\hline \multirow{2}{*}{ Agency } & \multicolumn{3}{|c|}{ Puff parameter } & \multirow{2}{*}{$\begin{array}{c}\text { \% of filter ventilation } \\
\text { zone blocked }\end{array}$} \\
\cline { 2 - 4 } & $\begin{array}{c}\text { Volume } \\
(\mathrm{mL})\end{array}$ & $\begin{array}{c}\text { Duration } \\
(\mathrm{s})\end{array}$ & $\begin{array}{c}\text { Frequency } \\
(\mathrm{s})\end{array}$ & 0 \\
\hline FTC/ISO/CORESTA & 35 & 2 & 60 & 100 \\
Canada - intense & 55 & 2 & 30 & 50 \\
Massachusetts - intense & 45 & 2 & 30 & 0 \\
FTC-intense & 55 & 2 & 30 & \\
(under consideration) & & & & 0 \\
\hline
\end{tabular}

\section{INACCURATE INTERPRETATIONS BY BIALOUS AND YACH}

BIALOUS and YACH (1) make important statements which are not supported by the facts. On page 97 of their article they state:

Both the ISO and the FTC methods, as well as Germany's DIN method, are derived from CORESTA Standard Methods ...

and on page 98 they make reference to "... the determination of standards by the [tobacco] industry, without the participation of other interested parties ..."

As indicated in Section 3.1 above, the FTC determined its method in 1966 (28). The FTC method actually preceded the CORESTA method (42) by more than two years.

On page 99 BIALOUS and YACH state that "... CORESTA resists any interference with its proposed standards, and make efforts to keep overall control of the situation and the outcomes of ISO meetings". To support this assertion they quote three sentences from the minutes of the CORESTA Scientific Commission meeting held in Japan on 3 November 1996:

\footnotetext{
"The subgroup routine analytical chemistry has prepared a series of editorial updates of the smoking methods. Shortly before the ISO meeting in Williamsburg in October 1996, the British body (BSI) sent a number of proposals on the same topic and at the meeting it was clear that some nonCORESTA participants, in particular government labs, were eager to have their say, with the support of ISO itself.

"After the meeting of ISO, it is clear that if the CORESTA methods and ISO standards are to remain close or identical, it is not desirable to publish revised CORESTA methods immediately, but to hand out a draft and wait for eventual ISO amendments, then publish a revised version very close to the ISO revised standard."
}

I was president of the Scientific Commission in 1996 and chaired the meeting quoted above. The broad facts are that the ISO machine-smoking standards published in 1991 (41) were approaching their five-year review (see Section 3.4 above). ISO had asked all its 33 national standard organisations, and CORESTA (a liaison member), to submit any revisions which were considered necessary. The Routine Analytical Chemistry Sub Group within CORESTA submitted several revisions, mostly clarification points on methodology and a suggestion that the chemical analysis of nicotine in the method should be based on capillary column gas chromatography rather than packed column gas chromatography. Various national standards organisations also submitted their suggested revisions to ISO. The BSI committee, consisting of representatives of four UK tobacco companies and the Laboratory of the Government Chemist, submitted a list of small editorial/clarification revisions. Since both the CORESTA Routine Analytical Chemistry Sub Group and the BSI sets of revisions had come from some of the same laboratories by different routes, the CORESTA Scientific Commission wanted to ensure that revisions to the CORESTA methodology were consistent with revisions to the ISO methodology. BIALOUS and $\mathrm{YACH}$ do not quote the next sentence in the minutes in which it is stated that ". . . the final revised version of the CORESTA smoking methods be published only after ISO's additional amendments will be known ( is exactly what happened. In other words, CORESTA postponed an update to the existing CORESTA methodology until ISO had finished its deliberations. Once the ISO process was completed, CORESTA updated its own methods in order to ensure that the issues covered in ISO were adequately covered in the CORESTA methods.

This has been a lengthy explanation of a relatively small point. However, I have given it in some detail to show that BIALOUS and YACH, by selectively quoting part of a document and without putting it into context, are wrong to assert that CORESTA strives to control the outcome of ISO matters.

BIALOUS and YACH also quote another section from the same minutes, on the subject of the development of methods for smoking "roll-your-own" tobacco products, when ". . . the matter of participation of non-CORESTA bodies" was discussed. As president of the Scientific Commission of CORESTA, I felt that all laboratories having relevant facilities should participate in CORESTA's work, whether or not they were actually members of CORESTA. Indeed, at that meeting it was recommended that the UK Laboratory of the Government Chemist and the German DIN be invited to participate in the collaborative experiments. Since that Scientific Commission meeting in 1996, several other non-CORESTA member laboratories in the UK, USA and Canada have also been invited to participate in the development of a variety of CORESTA methods: sidestream smoke, special analytes and pesticides. If BIALOUS and YACH had read or quoted minutes 
from other Scientific Commission meetings they would have realised that their claim that ". . . CORESTA resists any interference with its proposed methods" is not supported by the facts.

On page 98 of their article, BIALOUS and YACH (1) note that the chairman of ISO Technical Committee 126 is P.I. Adams and that he used to work for Imperial Tobacco, UK, has a patent on a ventilated cigarette filter, and was a former president of the CORESTA Technology Group. They do not note that this is the very same P.I. Adams who presented the paper on human smoking data (34) at the 1966 Tobacco Chemists' Research Conference in the USA, referred to in Section 3.1. In fact Adams was one of the pioneers in the study of human smoking behaviour and went on to conduct and publish other studies on the subject (68-70). BIALOUS and YACH make no further comment on Adams' background but it appears in the middle of a section where they appear to infer that the tobacco industry has undue influence over ISO's activities. It is entirely logical and desirable that the chairman of the ISO Tobacco Committee should be a recognised and respected expert in tobacco science. This is completely consistent with the situation within the other 186 Technical ISO Committees, where the chairman is of course an expert on the subject matter of the committee, obtained through work within the relevant industry or research organisation. Adams' scientific background in human smoking behaviour is highly relevant to smoking-machine methodology. Indeed, it is difficult to think of a more suitable background. He has been involved with ISO work since 1973 and, as chairman, has provided unbiased and expert guidance to all of the work of ISO Technical Committee 126 over the last sixteen years.

On page 97 of their article BIALOUS and YACH (1) state that ". . . cigarette design has been used to 'cheat' the smoking machine, providing lower tar and nicotine readings by machine versus human smoking, a fact that has also been widely discussed in the scientific literature." They repeat the cheating allegation again in their discussion of ventilated filter cigarettes on page 100 where they state:

Holes in cigarette filters were invented to 'cheat' smoking machines that measure tar and nicotine yield by allowing air to flow into the machine and diluting the concentration of cigarette smoke components. It has been demonstrated that human smokers compensate for lower delivery by, among other things, blocking those holes.

The first sentence of this latter quotation is an incorrect statement. The second sentence is a partial statement of fact in which tobacco industry scientists were amongst the first to publish in the scientific literature (e.g. 71) and have recently published reviews on the subject $(47,56)$. Filter ventilation is one of a variety of cigarette design tools used to reduce the yields of "tar" and other components in cigarette smoke. Other techniques include filters, modified cigarette paper and modified forms of tobacco and tobacco blends. All of these techniques are well documented in the scientific literature, see for example, (72) and (73). Lower "tar" cigarettes have been developed in response to a variety of health and regulatory authorities over the last forty years. To suggest that such cigarettes are deliberately designed to cheat the consumer is simply untrue.

This critique of some of BIALOUS and YACH's statements is partial. It has been done to illustrate that by juxtapositioning isolated quotations from selected documents, without setting them in context, they have come to wrong conclusions and made statements that are misleading or untrue.

\section{HEALTH CLAIMS ABOUT LOW "TAR" CIGARETTES}

On page 97 of their article, BIALOUS and YACH (1) state, quite correctly, that: "No health claims can be made based on the ISO/FTC tar and nicotine yield measurements." Later in their article, on page 101, they state that the tobacco industry promotes low "tar", or "light" cigarettes ". . . insinuating health benefits from these lower tar and nicotine products, when no health benefits exist." In this Section, two aspects will be briefly explored: (i) who has made the claims that lower "tar" cigarettes are a less hazardous form of smoking, and (ii) whether such claims are justified.

\subsection{Statements made by health scientists and authorities}

In 1957 WYNDER et al. (74) reported that carcinoma production in mouse-skin painting experiments with cigarette smoke condensate showed a dose response and prompted them to state at the time:

\begin{abstract}
Although it is difficult to estimate a comparable exposure for man, the human data in line with the animal data indicate that a reduction in total tar reduction will be followed by a decrease in tumor formation. For this reason, measures directed towards this reduction are of utmost importance.
\end{abstract}

Other studies over the next eight years confirmed the doseresponse results of WYNDER et al. (75). WYNDER, at the time working at the Sloan-Kettering Institute for Cancer Research in New York, was one of the pioneers in the epidemiology of smoking and lung cancer as well as research on the carcinogenesis of tobacco smoke. In a paper in the British Medical Journal in 1957 (76) he suggested that filters on the cigarette which would reduce the "tar" levels in smoke by $40 \%$ should be used (at that time most cigarettes were unfiltered).

In the UK in 1962 the first Royal College of Physicians report on smoking and health (77) recommended the use of filter cigarettes for smokers who could not quit, because of their generally lower "tar" content than plain cigarettes. The report also recommended that the government should measure and publish the "tar" and nicotine content of cigarette brands.

Reviewing all of the available evidence from biological testing and the epidemiology of lung cancer in their classic 1967 book on tobacco smoke (75), WYNDER and HOFFMANN wrote that ". . . a reduction of 'tar' yields of cigarettes must be a major aim in this area of research." [They were referring to research on cigarette filters in tobacco companies.] 
Table 3. "Tar" bands defined by the UK Department of Health and Social Security

\begin{tabular}{lc}
\hline From 1972 & 'Tar' yield per cigarette $(\mathrm{mg})$ \\
\hline Low & $\leq 10$ \\
Low-to-middle & $11-16$ \\
Middle & $17-22$ \\
Middle-to-high & $23-28$ \\
High & $\geq 29$ \\
\cline { 1 - 1 } From 1985 & \\
\hline Low & $\leq 10$ \\
Low-to-middle & $10-14$ \\
Middle & $15-17$ \\
High & $\geq 18$ \\
\hline
\end{tabular}

In 1976 GoRI, of the National Cancer Institute in Bethesda, MD, USA, published a paper in which he analysed published epidemiological data on smoking and lung cancer (78). He concluded that the reduction of the total "tar" content of cigarette smoke should result in a reduction in the disease incidence.

In 1975 the World Health Organisation (WHO) recommended (79) that ". . . those who are unable to stop smoking should try to reduce their exposure to such harmful substances in smoke as tar, nicotine and carbon monoxide". They also recommended that legislation action should be considered ". . . to adopt a system of differential taxation so as to discourage the smoking of cigarettes with a relatively high tar, nicotine, and carbon monoxide yield." Again, in 1979 the WHO reiterated these recommendations and they also recommended (80) that:

Upper limits should be established for appropriate emission products of cigarettes. These limits (currently for tar, nicotine, and carbon monoxide) should be progressively lowered as rapidly as possible.

This is, in fact, precisely what the European Union has done, with its "tar" ceiling of $15 \mathrm{mg}$, introduced in 1993, lowered to $12 \mathrm{mg}$ in 1999 and then to $10 \mathrm{mg}$ in the next four years. In 1985 PETO and DOLL (81) examined the trends in the epidemiology of smoking and lung cancer, including information on the epidemiology of smoking low "tar" cigarettes. In the article they went on to suggest ways in which governments should discourage people from smoking. They stated:

Another message that we must get across (at least to governments, although perhaps not to individual smokers) is the importance of decreasing tar-deliveries. The epidemiological evidence strongly suggests that, even without any substantial changes in cigarette sales, practicable reductions in tar levels may help to reduce lung-cancer mortality.

They concluded their paper with the statement:

[Reductions in tar levels] may do little for vascular or respiratory disease, but they may well offer one of the more immediately practicable means of avoiding many of the lung-cancer deaths that we can otherwise expect during the first decades of the next century.
Both Peto and Doll are eminent epidemiologists at Oxford University in the UK. Sir Richard Doll, along with Bradford Hill, was the pioneer in linking the incidence of lung cancer to smoking in 1950.

At a lecture to the Royal College of Physicians in London in 1989 (82), Sir Peter Froggatt, Chairman of the UK Government's Independent Scientific Committee on Smoking and Health from 1981 to 1991, reiterated the view that the "tar" levels in cigarette smoke should be reduced. The 1990 European Economic Community Council Directive concerning the introduction of "tar" ceilings on all cigarettes sold in member states in Europe (49), stated quite unambiguously that "the higher the tar content of smoked tobacco, the greater the risk of lung cancer". In 1998 the UK Scientific Committee on Tobacco and Health reiterated the advice when it concluded: "A policy of further tar reductions in manufactured cigarettes should be pursued without compromising the message of the importance of not smoking" (83).

As a result of such statements from the health community, government agencies world-wide started to produce lists of the "tar" yields of cigarettes. From 1972 in the UK, for example, the Department of Health and Social Security (DHSS) began publishing tables which ranked the "tar" yields of brands in ascending order. These tables were displayed in posters and leaflets in doctors' surgeries, hospitals, clinics and pharmacy shops across the UK (84). The tables were accompanied by simple advice to smokers, essentially to give up smoking but if the individual continues to smoke they should smoke fewer cigarettes, leave longer butt lengths and select brands with "tar" yields as low as possible. It was also pointed out that small differences in "tar" yields of up to $2 \mathrm{mg}$ were probably insignificant.

The DHSS tables also divided the cigarettes into high, middle or low "tar" brands - see Table 3. Ironically, these DHSS tables were probably the first publication to use the term "low tar" in the UK

So how did the tobacco industry react to this consistent advice from eminent scientists and health authorities over more than forty years, to reduce the "tar" level of cigarette smoke? Has the tobacco industry itself claimed that low "tar" cigarettes are safer? In many countries the "tar" levels in cigarette smoke have been gradually reduced. Data for reductions in the US market are summarised in (23). In the UK the development of lower "tar" cigarettes has been undertaken in association with various government bodies, in particular the UK Independent Committee on Smoking and Health. The reductions in "tar" yields have been accomplished by the use of filters and filter ventilation, modified cigarette paper and modified forms of tobacco and tobacco blends (e.g. 72 and 73).

In the UK the sales-weighted average "tar" level has fallen from $35 \mathrm{mg}$ in the early 1960s to $10 \mathrm{mg}$ today (85). A "tar" ceiling of $15 \mathrm{mg}$ was introduced for all cigarettes sold in the European Community in 1993, reducing to $12 \mathrm{mg}$ in 1997 , i.e. all cigarettes sold must have a "tar" yield below $12 \mathrm{mg}$. This will be reduced to $10 \mathrm{mg}$ in the next four years. 


\subsection{Smoker compensation}

Of course, all of the above recommendations on reducing "tar" assume that smokers do not fully compensate for the "tar" reduction by smoking more cigarettes or puffing harder. Compensation has been studied for decades, (e.g. 71), and was considered as part of the UK's product modification programme (82). That programme determined that while compensation was likely to occur to some extent, it was not complete and hence lower "tar" was likely to be associated with some reduction in risk for some diseases $(86,87)$. SCHERER has recently reviewed all of the scientific literature on smoking compensation (56). He concludes that while human smoking behaviour is highly variable, on average partial compensation does occur shortly after smokers switch to cigarettes with different yields to their usual brand. Changes in the puff volume are the most probable mechanism of compensatory smoking. From all of the data taken as a whole, it would appear that the mean compensation is about $50 \%$. Thus, for example, on average a smoker who switches to a cigarette with a "tar" yield $50 \%$ lower than his/her current brand as measured on a smoking machine (ISO standard conditions) will actually receive a "tar" yield $25 \%$ lower than that received from their original cigarette. Consequently, it may be expected that, in general, smokers switching from a higher to a lower "tar" yield cigarette will obtain a reduction in smoke component uptake.

There were no data available in SCHERER's review on whether smokers who had switched for a long time, or smokers who only ever smoked very low "tar" cigarettes, had different smoking behaviours to short-term switchers. More research is needed to assess the actual amount of smoke taken by people who smoke very low "tar" cigarettes.

\subsection{Statements on the effect of smoking reduced "tar" cigarettes}

As a result of the "tar" reduction programme in the UK, and including knowledge of the partial compensation that occurs in smokers, the Independent Scientific Committee on Smoking and Health (ISCSH) concluded in 1988 (88):

\footnotetext{
We consider that past reductions in the yields of tar and associated cigarette smoke components have reduced the risk of lung cancer and possibly of chronic obstructive airways disease. We would expect future reductions to further reduce these risks. Past reductions on the other hand have probably had little impact on the incidence of ischaemic heart disease. We conclude that overall the lower tar policy has been beneficial to the health of the public.
}

The ISCSH (89) also recommended that "Government and the tobacco industry should consider what further action could be taken to persuade more smokers to favour low tar brands". The ISCSH consistently advised people not to smoke but ". . . to encourage health-conscious but recalcitrant smokers, new products were introduced in the low tar band ( $<10 \mathrm{mg} /$ cigarette) and smokers were encouraged by advice and selective advertising to switch to them" (87).
In 1996, the chairman of this government committee, Sir Peter Froggatt, and Cheryl Swann published a summary of the work of the UK Tobacco Products Research Trust. This charitable trust was set up by the ISCSH in 1982 and up until 1996 sponsored 37 projects at universities, medical research institutes etc, dealing with aspects of cigarette product modification. In summarising some projects of the trust, in which epidemiological trends from 1967 to 1982 were investigated, SWANN and FROGGATT wrote “. . . about one quarter of deaths from lung cancer, coronary heart disease and possibly other smoking-related diseases would have been avoided by lowering tar yields from $30 \mathrm{mg}$ to 15 mg/cigarette" (90).

WALLER and FROGGATT, in a paper to the British Medical Bulletin in 1996 (87) in which they considered both partial compensation and epidemiological trends, also made the point that the reduction in the "tar" levels of cigarettes had contributed to "... . reducing lung cancer mortality, especially in the younger age group (who have not been exposed to high tar products in their shorter smoking history) ..."

The US National Cancer Institute made a more cautious statement on the health benefits of low "tar" cigarettes in 1996 (60):

The smoking of cigarettes with lower machine-measured yields has a small effect in reducing the risk of cancer caused by smoking, no effect on the risk of cardiovascular diseases, and an uncertain effect on the risk of pulmonary disease. A reduction in machine-measured tar yield from $15 \mathrm{mg}$ tar to $1 \mathrm{mg}$ tar does not reduce relative risk from 15 to 1 .

\subsection{Comments by tobacco industry scientists}

The above statements on the possible health benefits were made by health experts and not by the tobacco industry. To my knowledge, no overt statement has ever been made by the tobacco industry to the public (consumers or the scientific community) that smoking a low "tar" cigarette is a safer form of smoking. The only statement of any relevance that I am aware of was published in 1978 by Dr. S.J. Green, Director of Research and Development of British American Tobacco. In a paper on the ranking of "tar" and nicotine yields from UK cigarettes by the UK Department of Health and Social Security, DHSS, (59) he commented:

\footnotetext{
Presumably the main objective in publishing the ranking of cigarette brands ... is to encourage smokers to choose their cigarettes using better information. There is some evidence (Hammond et al, 1976; Dean et al, 1977; Bross and Gison, 1986; Wynder, Mabuchi and Beattie, 1970) which some interpret to show that the incidence of diseases associated with smoking should be reduced when cigarettes with lower deliveries of some components are smoked. If this is correct it may be argued, therefore, that it is reasonable to encourage smokers to reduce the general level of tar available for inhalation. If the information in ranking tables helps smokers so to choose it may be considered that, as a far as simple tables (such as the DHSS list . . .) are concerned, there is some degree of validity.
}

This very cautious statement, in a scientific book, is hardly supportive of BIALOUS and YACH's allegation (1) that the 
tobacco industry "claims that cigarettes with lower levels of tar and nicotine were less harmful".

However, the statistics that demonstrate the real increased risks of smoking also show that these risks are lower in groups of people who smoke less, start smoking later, quit earlier and smoke fewer cigarettes. Given such doseresponse relationships, it might be thought logical that less smoke from lower "tar" cigarettes would be associated with less risk than more smoke from higher "tar" cigarettes. The science is not sufficiently developed to demonstrate whether or not this is the case for very low "tar" cigarettes.

\section{CONCLUSIONS}

a) The techniques relevant to the machine-smoking of cigarette were developed and refined throughout the 20th century. The first standard was specified by the FTC in the USA in 1966. The CORESTA Recommended Method, similar in many respects to that of the FTC, was developed after the FTC Standard and was published in 1969.

b) Although the specified puffing parameters were essentially identical, there were differences in the smoking-machine conditions, the method of smoke collection, analysis and butt lengths specified in the various standards of the FTC, CORESTA, ISO, and those used in the UK, Germany, Canada, Australia, New Zealand and Japan. These differences resulted in about a $10 \%$ difference in the "tar" yields of a cigarette measured using the different standards. These differences in methodology were harmonised in a common ISO Standard Method in 1991, following a considerable amount of inter-laboratory comparisons of the developing methodology undertaken by CORESTA.

c) Following revision of the ISO Standard Method, various countries changed their standard method to the ISO Standard Method in the early 1990s. As a result of this, machine smoke yields of some brands determined in the UK, for example, decreased by up to $0.5 \mathrm{mg}$ "tar", while smoke yields determined in Canada, for example, increased by up to $3 \mathrm{mg}$ "tar" for some brands. In the USA the slightly different FTC Standard still continues to be used, while Japan continues to use different butt lengths in its standard (Table 1) - Japan is likely to change to the ISO Standard in 2002.

d) The purpose of the smoking-machine standards is to determine the "tar", nicotine and carbon monoxide content of cigarette smoke when the cigarette is smoked under precisely defined conditions, and hence to allow a comparison of the yields from different cigarettes. Such yields are not predictive of the yields humans obtain when smoking, nor were they ever expected to be so, since no two smokers smoke exactly the same nor does a smoker smoke a cigarette the same way on every occasion. This purpose has been stated consistently many times, originally by the FTC in 1967, and subsequently in the scientific literature, published by the tobacco industry and health/regulatory authorities, over the last 35 years.

e) Compensation by smokers when switching to a low "tar" cigarettes has been discussed in the scientific literature for almost 40 years. The phenomenon was first published by the tobacco industry and tobacco industry scientists have published many papers on the subject. The available evidence, albeit limited, indicates that compensation is partial in the short term (up to a few weeks), and that smokers switching from a higher to a lower "tar" yield cigarette do obtain a reduction in smoke yield.

f) Since the 1950s numerous public health scientists have advocated that lower "tar" cigarettes should be developed on the grounds that they may represent a less hazardous form of smoking. Health authorities have consistently advised smokers to quit, but for those who choose to continue to smoke that they should smoke lower "tar" cigarettes (while at the same time advocating that the best way to avoid risks is not to smoke). The tobacco industry has responded to these health authorities by developing cigarettes with lower "tar" but has also followed public health advice by not advertising lower "tar" cigarettes as safe cigarettes.

g) By ignoring much of published scientific literature, and concentrating on a few highly selective quotations from internal company memos, BIALOUS and YACH (1) have, perhaps inadvertently, made factual errors, drawn wrong conclusions, and written inaccurate statements on many aspects of the subject.

Acknowledgements: I would like to thank the following colleagues for making many helpful comments and suggestions during the preparation of this review, supplying references and other information, and checking dates of events: Leslie Lewis, John Lauterbach, Alan Rodgman and David Townsend (USA), Peter Adams, Barry Camm, Keith Darrall, Mike Dixon, Harry Dymond, Chris Proctor, Val Rice and Paul Sadler (UK), François Jacob (France), Manuel Bourlas and Neil Sinclair (Switzerland), Hans Thomsen (Denmark), Patrick Dunn and Andrew Porter (Canada), Chris Murray (Australia) and Takeshi Sakaki (Japan).

\section{REFERENCES}

1. Bialous, S.A. and D. Yach: Whose standard is it, anyway? How the tobacco industry determines the International Organization for Standardization (ISO) standards for tobacco and tobacco products; Tob. Control 10 (2001) 96-104.

1a. Baker, R.R.: Letter to the Editor; Tob. Control 10 (2001) 394.

1b. Jacob, F.: Letter to the Editor; Tob. Control 10 (2001) 394-395.

1c. Bialous, S.A. and D. Yach: Authors' Reply; Tob. Control 10 (2001) 395-396.

2. Wynder, E.L. and D. Hoffmann: Tobacco and tobacco smoke; Studies in experimental carcinogenesis; Academic Press, New York and London, 1967, pp 94-105. 
3. DeBardeleben, M.Z., J.E. Wickham and W.F. Kuhn: The determination of tar and nicotine in cigarette smoke from an historical perspective; Rec. Adv. Tob. Sci. 17 (1991) 115-148.

4. Pfyl, B.: The determination of nicotine in tobacco smoke, II; Z. Unters. Lebensmittel 66 (1933) 501-509.

5. Bradford, J.A., W.R. Harlan and H.R. Hanmer: Nature of cigaret smoke: technic of experimental smoking (sic); Indust. Eng. Chem. 28 (1936) 836-839.

6. Keith, C.H. and J.R. Newsome: Quantitative studies on cigarette smoke. I. An automatic smoking machine; Tob. Sci. 1 (1957) 51-57.

7. Mumpower II, R.C., J.E. Kiefer and G.P. Touey: Effect of the duration of a constant-volume puff on the efficiency of cigarette filters; Tob. Sci. 5 (1961) 31-35.

8. Dube, M.F. and C.R. Green: Methods of collection of smoke for analytical purposes; Rec. Adv. Tob. Sci. 8 (1982) 42-102.

9. Wartman, Jr., W.B., E.C. Cogbill and E.S. Harlow: Determination of particulate matter in concentrated aerosols. Application to analysis of cigarette smoke; Anal. Chem. 31 (1959) 1705-1709.

10. Grob. K.: Gas chromatography of cigarette smoke. Part III. Separation of the overlap region of gas and particulate phase by capillary columns; J. Gas Chrom. 3 (1965) 52-56.

11. Holmes, J.C. and W.B. Cridlin: Moisture in the total particulate matter and gas phase of cigarette smoke; J. Assoc. Off. Agric. Chem. 43 (1960) 515-518.

12. Crowell, E.P., W.F. Kuhn, F.E. Resnik and C.J. Varsel: The determination of moisture in total particulate matter of cigarette smoke by near-infrared spectrophotometry; Tob. Sci. 5 (1961) 54-57.

13. Jarrell, J.E. and J.E. Wickham: The determination of moisture in the total particulate matter of cigarette smoke; Tob. Sci. 6 (1962) 154-157.

14. Avens, A.W. and G.W. Pearce: Silicotungstic acid determination of nicotine: errors involved and a new technique for steam-distillation of nicotine; Indust. Eng. Chem. -Anal. Ed. 11 (1939) 505-508.

15. Willits, C.O., M.L. Swain, J.A. Connelly and B. Brice: Spectrophotometric determination of nicotine; Anal. Chem. 22 (1950) 430-433.

16. Griffith, R.B. and R.N. Jeffrey: Improved steamdistillation apparatus: application to determination of nicotine in green and dry tobacco; Anal. Chem. 20 (1948) 307-311.

17. Cundiff, R.H. and P.C. Markunas: Determination of nicotine, nornicotine and total alkaloids in tobacco; Anal. Chem. 27 (1955) 1650-1653.

18. Griffith, R.B.: The rapid determination of total alkaloids by steam distillation; Tob. Sci. 1 (1957) 130-137.

19. Quin, L.D.: Alkaloids of tobacco smoke. I. Fractionation of some tobacco alkaloids and of the alkaloid extract of burley cigarette smoke by gas chromatography; J. Org. Chem. 24 (1959) 911-914.

20. Harvey, W.R., C.E. Badgett and F.E. Resnik: Nicotine alkaloids in tobacco leaf, cigarette filler and particulate matter of smoke by acid-methanol extraction; Tob. Sci. 11 (1967) 84-86.

21. Charles, J.L., H.M. Stahr and R.M. Ikeda: Automated determination of total particulate matter of cigarette smoke; Tob. Sci. 13 (1969) 54-58.

22. Peeler, C.L.: Cigarette testing and the Federal Trade Commission: a historical overview; in: Smoking and Tobacco Control. National Cancer Institute Monograph 7. The FTC cigarette test method for determining tar, nicotine and carbon monoxide of U.S. cigarettes. Report of the NCI expert committee. National Institute of Health, Bethesda, MD, U.S.A., 1996, Chapter 1.

23. Rodgman, A.: FTC "tar" and nicotine in mainstream smoke: a retrospective; Rec. Adv. Tob. Sci. 23 (1997) 5-74.

24. Borgerding, M.F.: The FTC method in 1997 - what alternative smoking condition(s) does the future hold? Rec. Adv. Tob. Sci. 23 (1997) 75-151.

25. Report of the Advisory Committee to the Surgeon General of the Public Health Service: Smoking and Health; U.S. Department of Health, Education and Welfare, DHEW Publ. No. (PHS) 1103, 1964.

26. Federal Trade Commission: News Release, 25 March 1966.

27. Ogg, C.L.: Determination of particulate matter and alkaloids (as nicotine) in cigarette smoke; J. Assoc. Off. Agric. Chem. 47 (1964) 356-362.

28a. Federal Trade Commission: Cigarettes and related matters: methods to be employed in determining tar and nicotine content; Fed. Register 31 (1966) 14, 278.

28b. Federal Trade Commission: Cigarettes: testing for tar and nicotine content; Fed. Register 32 (1967) 11,178.

29. Federal Trade Commission: New Release, 1 August 1967.

30. Pillsbury, H.C., C.C. Bright, K.J. O'Connor and F.W. Irish: Tar and nicotine in cigarette smoke; J. Assoc. Off. Anal. Chem. 52 (1969) 458-462.

31. Federal Trade Commission: "Tar" and nicotine content of 59 varieties of cigarette; November 1967.

32. Ogg, C.L. and E.F. Schultz: Collaborative study of the determination of tar and nicotine in cigarette smoke; J. Assoc. Off. Anal. Chem. 53 (1970) 659-672.

33. Federal Trade Commission: "Tar", nicotine and carbon monoxide of the smoke of 187 varieties of cigarettes; March 1981.

34. Adams, P.I.: Measurements on puffs taken by human smokers; Paper presented at $20^{\text {th }}$ Tobacco Chemists' Research Conference, Winston-Salem, NC, U.S.A., Programme Booklet and Abstracts, no. 31, 1966.

35. Bates, W.B., R.B. Griffith, E.S. Harlow, M. Senkus, and $\mathrm{H}$. Wakeham: Determination and reporting of total particulate matter, water in total particulate matter, and nicotine in cigarette smoke; Tob. Sci. 12 (1968) 192-196. (Reprinted from Virginia J. Sci. 18 (1967) 130-135.)

36. Bentley, H.R. and J.G. Burgan: Cigarette smoke condensate: preparation and routine laboratory estimation, $2^{\text {nd }}$ Ed.; Tobacco Manufacturers Standing Committee, London, UK, Research Paper 4, 1961. 
37. Johnson, J.C.: Development of machine smoking parameters for measurement of cigarette tar yield in the United Kingdom; J. Assoc. Off. Anal. Chem. 69 (1986) 598-600.

38. Rothwell, K. and C.A. Grant (Eds): Standard methods for the analysis of tobacco smoke; Tobacco Research Council, London, UK, Research Paper 11, 1972, $2^{\text {nd }}$ edition was published in 1974 and $3^{\text {rd }}$ edition was published in 1986.

39. British Standards Institute: Routine analytical cigarette smoking machine. Part 1. Specification and standard conditions; BS5668, 1987.

40a. Deutsches Institut für Normung: Analysis of tobacco and tobacco products - Machine smoking of cigarettes and determination of smoke condensate: requirements for an analytical smoking machine; DIN 10, 240, 1978.

40b. Deutsches Institut für Normung: Analysis of tobacco and tobacco products - Determination of alkaloids in cigarette smoke condensates - spectrophotometric method; DIN 10, 242, 1982.

41a. International Organisation for Standardisation: Routine analytical cigarette-smoking machine. Definitions and standard conditions; ISO 3308, 1991; replaced by revised edition in 2000.

41b. International Organisation for Standardisation: Tobacco and tobacco products. Atmosphere for conditioning and testing; ISO 3402, 1991; replaced by revised edition in 1999.

41c. International Organisation for Standardisation: Cigarettes. Determination of total and nicotine-free dry particulate matter using a routine analytical smoking machine; ISO 4387, 1991; replaced by revised edition in 2000.

41d. International Organisation for Standardisation: Sampling tobacco and tobacco products. Methods of sampling cigarettes; ISO 8243, 1991, current standard.

41e. International Organisation for Standardisation: Cigarettes. Determination of nicotine in smoke condensates - gas chromatographic method; ISO 10315, 1991; replaced by revised edition in 2000.

41f. International Organisation for Standardisation: Cigarettes. Determination of water in smoke condensates - gas chromatographic method; ISO 10362-1, 1991; replaced by revised edition in 1999 .

41g. International Organisation for Standardisation: Cigarettes. Determination of water in smoke condensates - Karl Fischer method; ISO 10362-4, 1994; current standard.

(The equivalent CORESTA methods are CORESTA Recommended Method Numbers 7, 8, 21 to 25, CORESTA Inf. Bull. No. 3 (1991) 112-179.

42. CORESTA Recommended Method No. 10: Machine smoking of cigarettes, determination of crude and dry smoke condensate; CORESTA Inf. Bull. No. 1 (1969) 24-33.

43. International Organisation for Standardisation: Routine analytical cigarette smoking machine. Specification for the machine and auxiliary equipment; ISO 3308, First edition, 1977. Now withdrawn and replaced by the standard in reference $41 \mathrm{a}$.
44. International Organisation for Standardisation: Cigarettes - determination of total and dry particulate matter using a routine analytical cigarette smoking achine - glass fibre filter smoke trap method; ISO 4387, First edition, 1987. Now withdrawn and replaced by the standard in reference $41 \mathrm{c}$.

45. International Organisation for Standardisation: Cigarettes - determination of total and dry particulate matter using a routine analytical smoking machine. An electrostatic smoke trap method; ISO 8453, First edition 1987. Now withdrawn and not replaced.

46. CORESTA Recommended Method No. 22: Routine analytical cigarette-smoking machine specifications, definitions and standard conditions; CORESTA Inf. Bull. No. 4 (1989) 28-53.

47. Baker, R.R. and L.S. Lewis: A review of the incidence and consequences of cigarette filter vent blocking among smokers; Beitr. Tabakforsch. Int. 19 (2001) 209-228.

48. Thomsen, H.V.: International reference method for the smoking of cigarettes; Rec. Adv. Tob. Sci. 18 (1992) 69-94.

49. European Economic Community: Council Directive 90/239/EEC 17 May 1990 on the approximation of the laws, regulations and administrative provisions of the Member States concerning the maximum tar yields of cigarettes; Official Journal L 137 (1990) 36-37.

50. International Organisation for Standardisation: Precision of test methods - Determination of repeatability and reproducibility for a standard test method by interlaboratory tests; ISO 5725, 1986.

51. CORESTA: Smoking methods. The determination of repeatability (r) and reproducibility $(\mathrm{R})$ for the measurement of: nicotine-free dry particulate matter, nicotine and water using CORESTA Recommended Methods 7, 8, 21, 22, 23, 25; CORESTA Inf. Bull. No. 3 (1991) 4-111.

52a. Federal Trade Commission: Up in smoke: the truth about tar and nicotine ratings, May 2000; Internet website: www.ftc.gov/bcp/conline/pubs/alerts/ smokealrt.htm

52b. Federal Trade Commission: "tar", nicotine, and carbon monoxide of the smoke of 1294 varieties of domestic cigarettes for the year 1998; 2000.

53. Creighton, D.E. and P.H. Lewis: The effect of smoking pattern on smoke deliveries, in: Smoking behaviour: physiological and psychological influences, edited by R.E. Thornton, Churchill Livingstone, London, 1978, pp 301-314.

54. Darrall, K.G.: Smoking machine parameters and cigarette smoke yields; Sci. Total Environ. 74 (1988) 263-278.

55. Schulz, W. and F. Seehofer: Smoking behaviour in Germany - the analysis of cigarette butts (KIPA); in: Smoking behaviour: physiological and psychological influences, edited by R.E. Thornton, Churchill Livingstone, London, 1978, pp 259-276.

56. Scherer, G.: Smoking behaviour and compensation: a review of the literature; Psychopharm. 145 (1999) $1-20$.

57. Fourth Report of the Independent Scientific Commit- 
tee on Smoking and Health (Chairman, Froggatt, Sir P.); Her Majesty's Stationery Office, London, 1988, Appendix 3.

58. CORESTA: Standard smoking methods: a CORESTA perspective; a) CORESTA Inf. Bull. No. 2 (1994) 54-57. b) Internet website: www.coresta.org.

59. Green, S.J.: Ranking cigarette brands on smoke deliveries; in: Smoking behaviour: physiological and psychological influences, edited by R.E. Thornton, Churchill Livingstone, London, 1978, pp 380-388.

The references included in Green's quotation in Section 6.4 of this review are:

59a. Hammond, E.C., L. Garfinkel, H. Seidman and E. Lew: Some recent findings concerning cigarette smoking: Presented at a meeting on "The Origins of Human Cancer" at Cold Springs Harbor Laboratory on September 14, 1976.

59b. Dean, G., P.N. Lee, G.F. Todd and A.J. Wicken: Report on a Second Retrospective Mortality Study in North-East England. Part 1. Factors related to mortality from lung cancer, bronchitis, heart disease and stroke in Cleveland County, with particular emphasis on the relative risks associated with smoking filter and plain cigarettes; Tobacco Research Council, Research Paper 14, Part 1, London, 1977.

59c. Bross, I.D.J. and R. Gibson, Risks of lung cancer in smokers who switch to filter cigarettes; Amer. J. PubHealth 58 (1968) 1396-1403.

59d. Wynder, E.L., K. Mabuchi and E.J. Beattie: The epidemiology of lung cancer. Recent trends; J. Amer. Med. Assoc. 213 (1970) 2221-2228.

60. National Cancer Institute Monograph 7: Smoking and Tobacco Control. The FTC cigarette test method for determining tar, nicotine and carbon monoxide of U.S. cigarettes. Report of the NCI expert committee. National Institute of Health, Bethesda, MD, U.S.A., 1996, pp. iii-Xx.

61. Rickert, W.S., J.C. Robinson, J.C. Young, N.E. Collinshaw and D.F. Bray: A comparison of the yields of tar, nicotine and carbon monoxide of 36 brands of Canadian cigarettes tested under three conditions; Prev. Med. 12 (1983) 682-694.

62. Rickert, W.S. and M.J. Kaiserman: A comparison of yields of "tar", nicotine and $\mathrm{CO}$ of 115 brands of Canadian cigarettes tested under six conditions; Paper presented at $51^{\text {st }}$ Tobacco Chemists' Research Conference, Winston-Salem, NC, U.S.A., Programme Booklet and Abstract, no. 7, 1997.

63. Borgerding, M.F. and L.S. Winkler: Effect of alternative puffing regimens on relative cigarette performance; Paper presented at $49^{\text {th }}$ Tobacco Chemists' Research Conference, Lexington, KY, U.S.A., Programme Booklet and Abstract, no. 47, 1995.

64. Taylor, C.R., Jr., J.R. Reid, M.A. Sudholt, K.F. Podraza, F.S. Hsu, M.F. Borgerding, J.A. Bodnar and J.F. Whidby: The 1999 Massachusetts benchmark study. Final report. (A Research Study Conducted after Consultation with the Massachusetts Department of Public Health (MDPH)). Presented to the MDPH on 24 July 2000. Compiled by M.F. Borgerding, J.A. Bodnar and D.E. Wingate.
65. Borgerding, M.F., J.A. Bodnar, F.S. Hsu, W.T. Morgan, K.F. Podraza, J.R. Reid, M. A. Sudholt, C.R. Taylor Jr., and J.F. Whidby: 1999 Massachusetts benchmark study to evaluate mainstream and sidestream cigarette smoke constituent yields. Part 1. General summary and overview of results; Part 2. Overview of mainstream results; Part 3. Overview of sidestream results; Part 4. Application of functional relationships to estimate mainstream and sidestream smoke yields; Papers presented at the $54^{\text {th }}$ Tobacco Science Research Conference, Nashville, TN, U.S.A., Programme Booklet and Abstracts, nos. 15, 16, 17 and 18, pp. 25-28, 2000.

66. Borgerding, M.F., J.A. Bodnar, K.F. Podraza, J.R. Reid, F.S. Hsu, M.A. Sudholt, C.R. Taylor, Jr., and J.F. Whidby: 1999 Massachusetts benchmark study to evaluate mainstream and sidestream smoke constituent yields - a summary of results; Paper presented at CORESTA Congress, Lisbon, Portugal, CORESTA Congress Inf. Bull., Abstract ST18, p. 162, 2000.

67. Kozlowski, L.T. and R.J. O'Connor: Official cigarette tar tests are misleading: use a two-stage compensating test; Lancet 355 (2000) 2159-2161.

68. Adams, P.I.: The influence of cigarette smoke yields on smoking habits; in: Smoking behaviour: physiological and psychological influences, edited by R.E. Thornton, Churchill Livingstone, London, 1978, pp. 349-360.

69. Adams, P.I.: Cigar smoking: measurement of the human smoking regime and its relationship to smoking machines; Paper presented at joint CORESTA/Tobacco Chemists' Research Conference, Williamsburg, VA, U.S.A., CORESTA Inf. Bull., Abstract 78, pp. 116-117, 1972.

70. Adams, P.I.: Changes in personal smoking habits brought about by changes in cigarette smoke yield; Paper presented at $6^{\text {th }}$ International Tobacco Scientific Congress, Tokyo, Japan, CORESTA Inf. Bull., Abstract G005, pp. 132-133, 1976.

71. Thornton, R.E. (Ed.): Smoking behaviour : physiological and psychological influences; Churchill Livingstone, London, 1978.

72. Rodgman, A. (Symposium Chairman): Design of low"tar" cigarettes; Rec. Adv. Tob. Sci., Volume 10, 1984.

73. Norman, A.: Cigarette design and materials; in: Tobacco - production, chemistry and technology, edited by D.L. Davis and M.T. Nielsen, Blackwell Science, Oxford, U.K., 1999, pp. 353-387.

74. Wynder, E.L., P. Kopf and H. Ziegler: A study of tobacco carcinogenesis. II. Dose-response studies; Cancer 10 (1957) 1193-1200.

75. ibid. reference 2, pp. 503-516.

76 Wynder, E.L.: Towards a solution of the tobaccocancer problem; Brit. Med. J. (1957) 1-3.

77. A report of the Royal College of Physicians of London on smoking in relation to cancer of the lung and other diseases: Smoking and Health; Pitman Medical Publishing Co. Ltd., London, U.K., 1962.

78. Gori, G.B.: Low-risk cigarettes: a prescription; Science 194 (1976) 1243-1246. 
79. World Health Organisation: Smoking and its effects on health. Report of a WHO expert committee; WHO, Geneva, Switzerland, 1975, Technical Report Series No. 568, pp 29-34.

80. World Health Organisation: Controlling the smoking epidemic, Report of the WHO expert committee on smoking control, WHO, Geneva, Switzerland, 1979, Technical Report Series No. 636, p. 72.

81. Peto, R. and R. Doll: The control of lung cancer; New Scientist (1985) 26-30.

82. Froggatt, Sir P.: Smoking and health: yesterday's lessons and tomorrow's agenda; lecture given to the Royal College of Physicians, London, October 1989.

83. Report of the Scientific Committee on Tobacco and Health (Chairman, Poswillo, D.); U.K. Department of Health, The Stationery Office, London, U.K., 1998, p. 14.

84. An example of such a poster is reproduced in reference 57, Appendix 7.
85. Source: Tobacco Manufacturers' Association, London.

86. Swann, C. and Sir P. Froggatt: The Tobacco Products Research Trust 1982-1996; The Royal Society of Medicine Press, London, U.K., 1996, pp. 26-32.

87. Waller, R.E. and P. Frogatt: Product modification; Brit. Med. Bull. 52 (1996) 193-205.

88. ibid. reference 57, paragraph 58, p. 18.

89. ibid. reference 57 , p. 11.

90. ibid. reference 86, pp 45-46.

Address for correspondence

Richard R. Baker

British American Tobacco,

Research \& Development Centre, Regents Park Road, Milbrook

Southampton, SO15 8TL

United Kingdom 